\title{
Strategi Komunikasi Dalam Menangani Krisis Organisasi
}

\author{
Oleh: \\ Lena Satlita \\ FIS UNY
}

\section{Abstrak}

Tidak ada satupun organisasi di dunia ini yang menginginkan krisis. Tetapi dalam banyak kejadian, krisis bisa datang tanpa disadari dan secara tiba-tiba menghentak dan mengguncangkan suatu organisasi. Krisis bisa bersumber dari internal maupun eksternal organisasi, yang menyebabkan tidak ada satupun organisasi yang tidak rentan terkena krisis.

Mengulur waktu atau membiarkan suatu krisis berkembang secara liar, adalah tindakan yang tidak bijaksana, sia-sia dan merugikan organisasi. Demikian pula halnya dengan berbohong atau berusaha menutup-nutupi suatu krisis. Kecanggihan teknologi telekomunikasi dan media komunikasi dewasa ini, membuat organisasi tidak dapat lagi menyembunyikan suatu krisis dáii telinga pers. Dalam hitungan detik, berita mengenai suatu musibah/krisis tersebar ke berbagai penjuru, menyebabkan penanggulangan krisis menjadi tidak lebih mudah.

Untuk menanggulangi krisis, diperlukan suatu perencanaan khusus yang dapat merespon, menghadapi dan menangani krisis dengan cepat dan tepat, yang di dalamnya memasukkan faktor komunikasi sebagai bagian penting dalam penyelesaian krisis. Melalui strategi komunikasi yang handal, ketidakpastian, konflik kepentingan, keterlibatan emosional, opini publik yang berkembang dapat dinetralisir sehingga tidak sampai menjurus pada ketidakpercayaan publik yang dapat menghancurkan organisasi.

Kata kunci: strategi komunikasi, krisis, organisasi.

\section{Pendahuluan}

Dalam beberapa dekade belakangan ini, hampir seluruh organisasi baik bisnis maupun non bisnis, organisasi besar maupun kecil, pernah mengalami krisis. Krisis bisa berwujud pemogokan massal, kebakaran, kecelakaan, bencana alam, skandal, pengambilalihan kepemilikan perusahaan oleh pihak lain, peraturan-peraturan baru yang merugikan dan berbagai bentuk kesulitan lainnya. Krisis- krisis yang terjadi di Indonesia maupun dunia seperti Krisis pencemaran lingkungan "Buyat" PT Newton, Krisis "tidak halalnya 
"Ajinomoto, Krisis "lemak babi" dalam susu Dancow, Krisis likuidasi Bank Suma, Krisis bencana alam "Tragedi Tsunami", Wabah Flu Burung, Krisis Kenaikan BBM, Peristiwa Chernobyll di Uni Soviet, Kapsul Tylenol dari perusahaan Johnson \& Johson di Amerika, menunjukkan tidak ada organisasi yang bebas resiko. Reputasi cemerlang yang dibina secara susah payah bisa musnah dalam sekejap sebagai akibat krisis mendadak yang tidak tertanggulangi.

Pada dasarnya, ada dua macam kemungkinan krisis, yakni (1) kemungkinan yang paling diperhitungkan; (2). Kemungkinan yang paling tidak diperhitungkan. Krisis yang paling diperhitungkan biasanya berkaitan erat dengan karakteristik atau bidang kegiatan yang digeluti oleh suatu organisasi. Sedangkan kemungkinan yang paling tidak diantisipasi adalah krisis-krisis eksternal yang kemungkinan terjadinya sangat kecil namun konsekuensinya tidak kalah berbahayanya. Hal-hal yang paling kecil sekalipun bisa berkembang menjadi sumber ancaman yang mengerikan.

Karena itu, setiap organsiasi tidak boleh mengabaikannya dan harus memiliki serangkaian kesiapan tersendiri untuk mengatasi krisis. Dari berbagai krisis yang telah disebutkan di atas, kita dapat melihat ada krisis yang terselesaikan dengan baik artinya tidak melumpuh- kan organisasi/perusahaan, tetapi ada juga krisis yang meluluhlantakkan organisasi/perusahaan tersebut. Hal penting yang dapat dipelajari dari organisasi/ perusahaan yang selamat dari krisis adalah kemampuannya untuk megelola krisis dan memasukkan faktor komunikasi sebagai bagian penting dalam penyelesaian krisis, sehingga krisis tidak menjadi berlarut-larut dan bertambah parah. Dalam mengantisipasi terjadinya krisis, organisasi sudah seharusnya membuat suatu Program Persiapan Krisis yang dapat diaplikasikan secara kongkrit bila terjadi krisis di organisasi yang bersangkutan, sehingga kedatangannya tidak mengejutkan dan tidak menghancurkan sistem itu sendiri.

\section{Pengertian, Sumber dan Katego-} ri Krisis

Apakah krisis itu? Darimana sumbernya? Mengapa muncul krisis? Bagaimana bentuknya? Apa dampak negatifnya bagi suatu organisasi? Dan bagaimana mengatasinya? Itulah pertanyaan yang kerap muncul apabila krisis menghadang suatu organisasi. Dari beberapa literatur, krisis diartikan dalam beberapa pengertian yaitu:" bencana, kesengsaraan atau marabahaya yang datang mendadak"; "bahaya yang datang secara berkala karena tidak pernah diambil tindakan memadai" dan "ledakan dari serangkaian peristiwa penyimpangan yang 
terabaikan sehingga akhirnya sistem menjadi tidak berdaya lagi".

Krisis menurut Barton (Ngurah Putra , 1999:84) adalah peristiwa besar yang tak terduga yang secara potensial berdampak negatif terhadap baik perusahaan maupun publik. Peristiwa ini mungkin secara cukup berarti merusak organisasi, karyawan, produk, jasa yang dihasilkan organisasi, kondisi keuangan dan reputasi perusahaan.

Caroline Sapriel (dalam Machfud 1998) mengatakan pada dasarnya krisis adalah suatu kejadian, dugaan atau keadaan yang mengancam keutuhan, reputasi, atau keberlangsungan individu atau organisasi. Hal tersebut mengancam rasa aman, kelayakan dan nilai-nilai sosial publik, bersifat merusak baik secara aktual maupun potensial pada organisasi, sedangkan organisasi itu sendiri tidak dapat segera menyele-saikannya.
Berbagai pengertian di atas menunjukkan, krisis dipandang sebagai suatu situasi atau kejadian yang lebih banyak punya implikasi negatif pada suatu organisasi daripada sebaliknya.

Mengenai penyebab timbuinya krisis, Shrivasta dan Mitroff (dalam Ngurah Putra 1999: 90) membagi krisis kedalam empat kategori berdasarkan penyebab krisis yang dikaitkan dengan tempat krisis. Pertama yang terkategori dalam penyebab teknis dan ekonomis. Kedua yang terkategori sebagai penyebab manusiawi, organisatoris dan sosial. Mereka juga mengkategorikan penyebab krisis dilihat dari sudut tempat asal atau kejadian di dalam atau di luar organisasi. Berdasarkan kategori tersebut di atas ada empat sel untuk melihat tipologi krisis, seperti tergambarkan pada bagan berikut ini: 


\section{Tipologi Krisis}

Teknis/Ekonomis

\begin{tabular}{|c|c|}
\hline $\begin{array}{l}\text { Sel } 1 \\
\text { - Kecelakaan kerja } \\
\text { - Kerusakan produk } \\
\text { - Kemacetan komputer } \\
\text { - Informasi yang rusak/hilang } \\
\text { Internal }\end{array}$ & $\begin{array}{l}\text { Sel } 2 \\
\text { - Perusakan lingkungan yang meluas } \\
\text { - Bencana Alam } \\
\text { - Hostile Takeover } \\
\text { - Krisis Sosial } \\
\text { - Kerusakan sistem besrkala luas } \\
\text { Eksternal }\end{array}$ \\
\hline $\begin{array}{l}\text { Sel } 3 \\
\text { - Kegagalan Beradaptasi/ melakukan } \\
\text { perubahan } \\
\text { - Sabotase oleh orang dalam } \\
\text { - Kemacetan organisasional } \\
\text { - On-site product tampering } \\
\text { - Aktivitas ilegal } \\
\text { - Penyakit karena pekeriaan }\end{array}$ & $\begin{array}{l}\text { Sel } 4 \\
\text { - Symbolic projection } \\
\text { - Sabotase orang luar } \\
\text { - Teroris, penculikan eksekutif } \\
\text { - Off site product tempering } \\
\text { - Counterfeiting (pemalsuan) }\end{array}$ \\
\hline
\end{tabular}

\section{Manusia/Organisasional/Sosial}

Menurut Otto Lerbinger (dalam Mazur \& White, 1998: 32) kategori krisis dapat dikelompokkan sebagai berikut:

Krisis teknologis (technological crisis). Dalam era pascaindustri ini makin banyak koorporasi yang tergantung pada kemajuan dan keandalan teknologi, sehingga bilamana teknologinya gagal maka akibatnya bagi masyarakat sangat dahsyat.

Krisis konfrontasi (confrontation crisis). Krisis timbul karena gerakan masa melakukan proses dan kecaman terhadap korporasi.

Krisis tindak kejahatan (crisis of malevolence). Krisis timbul sebagai akibat dari tindakan beberapa orang atau kelompok-kelompok terrorganisasi.

Krisis kegagalan manajemen (crisis of management failures). Krisis muncul karena terjadinya salah urus dan penyalahgunaan kekuasaan oleh kelompok-kelompok yang diberi kewenangan khusus.

Krisis ancaman-ancaman lain (crisis involving other threats to the organization). Dalam perkembangan sekarang, krisis terutama dapat berbentuk likuidasi, pencaplokan, dan merger perusahaan.

Linke mengkategorikan krisis dengan melihat proses atau waktu kejadian sebuah krisis. Menurut Lin- 
ke, krisis terbagi ke dalam empat jenis, yaitu:

1. The exploding crisis, krisis yang terjadi karena sesuatu yang diluar kebiasaan, misalnya kebakaran, kecelakaan kerja atau peristiwa yang dengan mudah dapat dikategorikan dan terkenali yang punya dampak langsung.

2. The immediate crisis, yakni sebuah kejadian yang membuat manajemen terkejut, namun masih ada waktu untuk mempersiapkan respon terhadap krisis tersebut, misalnya laporan media massa tentang sebuah perusahaan, pengumuman pemerintah tentang ambang batas pencemaran dan sebagainya.

3. The a building crisis, yakni sebuah krisis yang sedang berproses dan dapat diantisipasi, misalnya negosiasi dengan buruh.

4. The continuing crisis, yakni problem kronis yang memerlukan waktu panjang untuk muncul. la biasanya sangat kompleks dan kemunculannya tidak mudah, bahkan mungkin tidak dikenali sama sekali, misalnya krisis industri asbestos di Amerika Serikat (Ngurah, 1999:92).

Dengan demikian dapat disimpulkan bahwa penyebab krisis dapat berasal dari luar organisasi maupun dari dalam organisasi dan dapat dikategorikan menjadi: (1) Krisis yang disebabkan karena kesalahan manusia, (2). Karena kegagalan tekno- logi, (3). Karena alasan sosial (kerusuhan, perang, sabotase maupun teroris), (4). Karena berkaitan dengan vencana alam (natural disaster) dan (5). Karena ketidakbecusan manajemen.

Apapun penyebabnya, suatu krisis tidak dapat dibiarkan karena krisis merupakan suatu kejadian yang mempunyai lingkup luas kemasyarakat. Krisis secara potensial dapat mengakibatkan kerusakan jangka panjang pada citra perusahaan, baik kehilangan kepercayaan dari publik dan konsumen maupun melemahnya moral kerja karyawan.

Seperti dikatakan Rosady Ruslan (1999:73) suatu organisasi atau perusahaan yang mengalami krisis, dapat menimbulkan resiko sebagai berikut:

1. Intensitas masalah menjadi meningkat.

2. Menjadi sorotan publik, baik melalui liputan media massa, informasi yang disebarkan melalui mulut ke mulut.

3. Mengganggu kelancaran kegiatan dan aktivitas sehari hari, organisasi dan mengganggu nama baik serta citra organisasi.

4. Merusak sistem kerja, etos kerja, dan mengacaukan sendi-sendi organisasi secara total yang mengakibatkan lumpuhnya kegiatan.

5. Membuat masyarakat ikut-ikutan panik. 
6. Mengundang ikut campur tangan pemerintah, yang mau tidak mau harus turut mengatasi masalah yang timbul.

7. Dampak atau efek dari krisis tersebut tidak saja merugikan organisasi yang bersangkutan, tetapi juga masyarakat tertentu atau lainnya ikut merasakan akibatnya. Lingkup dampak akan dengan cepat meluas, disebabkan oleh kemajuan teknik di bidang komunikasi.

\section{Mengelola Krisis Organisasi}

Mengingat dampak negatif dan kerugian yang sedemikian besar, maka krisis tidak dapat dibiarkan saja tetapi perlu dikelola dengan baik. Langkah-langkah yang perlu dilakukan menurut Kasali (1999: 231-232) :

a. Identifikasi Krisis. Langkah ini dilakukan dengan melakukan penelitian secara kilat dan informal. Hari itu tim diterjunkan dan mengumpulkan data, hari itu juga kesimpulan harus ditarik.

b. Analisis Krisis. Semua masukan yang diperoleh, harus dilakukan analisis dengan cakupan yang luas, mulai dari analisis parsial sampai analisis integral yang kait mengkait.

c. Isolasi Krisis. Krisis ibarat sebuah penyakit menular. Sebelum menyebar luas, krisis harus dikarantinakan sebelum tindakan serius dilakukan. d. Pilihan Strategi. Sebelum mengambil langkah-langkah komunikar; untuk mengendalikan krisis, sebuah organisasi perlu melakukan penetapan strategi generik yang akan diambil. Ada 3 strategi generik untuk menangani krisis yaitu : (1). Strategi defensif, dengan langkah- langkah mengulur waktu, tidak melakukan apa-apa, membentengi diri dengan kuat: (2). Strategi Adaptif, dengan langkah-langkah mengubah kebijakan, modifikasi operasional, kompromi, meluruskan citra; dan (3). Strategi Dinamis, dengan melakukan langkah-langah merger dan akuisisi, investasi baru, menjual saham, meluncurkan produk ba$\mathrm{ru}$, menggandeng kekuasaan, melempar isu baru untuk mengalihkan perhatian.

e.Program Pengendalian. Program ini adalah langkah penerapan yang dilakukan menuju strategi generik yang dirumuskan. Umumnya strategi generik dapat dirumuskan sebelum krisis timbul dan dapat menjadi pedoman untuk mengambil langkah yang pasti, sedangkan program penngendalian biasanya disusun di lapangan ketika krisis muncul.

Rosady Ruslan (1999:83) mengacu apa yang telah dilakukan Ivy Lee, pakar public relations dalam menangani berbagai krisis di Amerika, mengatakan bahwa untuk me- 
nanggulangi krisis yang tengah berlangsung, perlu membentuk suatu program khusus yakni:

1.Menghadapi krisis dengan sistem case by case.

2. Menunjuk salah seorang sebagai juru bicara bagi pihak ketiga.

3. Memberikan pelatihan dan pengarahan bagi karyawan, apa yang dilakukan dan apa yang tidak boleh dilakukan.

4. Tidak berspekulasi terhadap suatu peristiwa, baik mengenai jumlah kerugian yang diderita akibat krisis itu terjadi maupun nilai uang dan materi lainnya sebelum ada angka yang pasti.

5. Membuka semua saluran informasi, tetapi harus dikoordinasikan lewat juru bicara yang telah ditunjuk, agar tercipta satu sumber informasi yang terkendali mengenai tahapan krisis hingga penyelesaiannya.

6. Tindakan terakhir adalah mengawasi dan mengevaluasi masalah yang telah dicapai atau yang belum diselesaikan dalam upaya mengurangi dampak dan efek krisis. Sejauh mana kerugian yang diderita, baik perusahaan maupun masyarakat lainnya, yang terseret menjadi korban dari krisis secara langsung dan tidak langsung.

Walaupun berbagai krisis yang dihadapi oleh suatu organisasi tanpa diawali munculnya gejala krisis, namum umumnya sebuah krisis menurut Kasali (1999: 226), mengalami berbagai tahap pertumbuhan mulai tahap warning stage (sinyal tanda bahaya), tahap akut, tahap kronik, dan tahap penyembuhan. Oleh karenanya penanganan suatu krisis organisasi seharusnya dilakukan sejak dini, ketika sinyal-sinyal memberi tanda bahaya, bahkan sebelum krisis itu terjadi. Ardianto \& Soemirat (2002: 184 ) mengatakan suatu krisis organisasi perlu ditangani dengan menggunakan strategi $3 P$, yaitu:

1. Strategi Pencegahan, adalah tindakan preventif melalui antisipasi terhadap situasi krisis. Dalam hal ini, organis si perlu memiliki kepekaan terhadap gejala-gejala yang timbul mendahului krisis.

2.Strategi Persiapan. Bilamana krisis tidak dapat dicegah sejak dini, strategi persiapan harus dilakukan dengan melalui dua langkah: (1) perusahaaan membentuk tim krisis yang terdiri dari pemimpin organisasi dan bagian lainnya yang terkait dengan krisis. Tim harus selalu berhubungan baik melalui surat, telepon, rapat, untuk memantau krisis dari waktu ke waktu.

3. Strategi Penanggulangan. Apabila strategi pencegahan dan persiapan tidak sempat dilaksaakakan, langkah yang terakhir diambil adalah strategi penangulangan, yaitu, masa kuratif. Dalam strategi penanggulangan 
terdapat langkah-langkah yang harus diambil sesuai dengan kondisi krisis:

(1). Kondisi krisis akut, pengamanan yang harus dilakukan melalui tahap-tahap: (a). Mengidentifikasi krisis, mencari penyebab timbulnya krisis; (b). Mengisolasi krisis,agar operasional organisasi tidak terganggu , agar efektivitas penanggulangan dapat ditingkatkan; (c). Mengendalikan krisis, agar krisis tidak meluas, krisis harus dikendalikan. Dalam hal ini keputusan tepat dan baik yang harus diambil. (2). Kondisi kesembuhan, ko:disi ini merupakan saat dimana organisasi menginstrospeksi mengapa krisis terjadi.

\section{Strategi Komunikasi Dalam Menghadapi Krisis Organisasi}

Kesalahan umum yang paling sering dilakukan oleh pimpinan organisasi yang tidak siap menghadapi krisis adalah dalam bidang komunikasi. Bentuk kesalahan yang dilakukan misalnya melakukan penolakan telah terjadi krisis, berbohong, spekulasi dan menolak untuk memberi informasi yang jujur dan komplit. Menurut Fearn-Banks, Haggart, Stubbart (dalam Ngurah Putra 1999) komunikasi pada saat organisasi menghadapi krisis menjadi sangat penting disebabkan antara lain karena krisis dicirikan oleh adanya ketidakpastian (uncertainty), konflik kepentingan (conflict of interest), kompleksitas dan keterlibatan emosional. Pada saat sebuah krisis terjadi, kebutuhan akan sebuah informasi biasanya begitu tinggi. Informasi yang cepat dan tepat akan mengurangi ketidakpastian.

Mengenai pentingnya komunikasi dalam penanganan krisis juga terungkap dari sebuah studi yang dilakukan Pinsdorf (Putra, 1999) yang membandingkan pengelolaan krisis yang terjadi pada perusahaan penerbangan nasional Jepang Japan Airlines yang mengalami kecelakaan pada tahun 1985 dan pengelolaan krisis oleh Pan Am, sebuah perusahaan Amerika yang mengalami kecelakaan pada tahun 1988. Dari berbagai respon dan reaksi kedua perusahaan tersebut, secara garis besar dalam penanganan krisis ada dua tindakan khas yang menjadi tuntutan yaitu : (1). Tindakan-tindakan yang bercirikan keterlibatan manajemen langsung dalam merespon krisis, yaitu segi apa yang harus dilakukan organisasi pada saat krisis dan (2), tindakan komunikasi, yakni apa yang harus dikatakan oleh organisasi yang sedang menghadapi krisis. Dalam merespon krisis, pemenuhan akan informasi yang terkontrol dengan baik dan informasi yang cepat dan tepat merupakan prioritas utama. Kekurangakuratan dalam komunikasi krisis justru dapat menyebabkan semakin terpuruknya sebuah or- 
ganisasi yang sedang menghadapi krisis.

Kajian di atas sesuai dengan pendapat Dindin M. Machfud, Senior Manager pada Divisi Public Relations PT Astra International Tbk (1998:50), " apabila gejala krisis mulai menampakkan diri, perusahaan perlu segera membentuk Tim Krisis yang solid, kompak dan kredibel. Tim ini bertugas untuk antara lain menghimpun, menginvetigasi, mengkaji data dan fakta secara kritis termasuk langkah-langkah: (1). Memulai proses pemulihan, (2). Menginformasikan kepada publik kunci mengenai langkah-langkah yang telah diambil dan akan dilaksanakan, (3). Mengaktifkan Pusat Krisis selama 24 jam, (4). Mengaktifkan Pusat Media dan (5). Memberikan penjelasan kepada pers mengenai perkembangan yang terjadi secara periodik- disamping menyiapkan siaran pers".

Komunikasi selama krisis menurut Sturges dkk (Ngurah Putra, 1999) mempunyai dua fungsi dasar, yakni (1) untuk menetralisir intervensi pihak ketiga yang mungkin dapat memperparah krisis yang sedang dihadapi oleh sebuah organisasi dan (2). Untuk menjaga agar karyawan dapat tetap memperoleh informasi yang tepat tentang organisasi tempat mereka bekerja, sehingga mereka menjadi tim yang memperkuat posisi organisasi dalam menghadapi krisis. Intervensi pihak ketiga umumnya datang dari media massa yang punya prinsip untuk menyampaikan setiap realitas sosial kepada khalayaknya, termasuk krisis yang sedang dialami sebuah organisasi.

Keberhasilan komunikasi krisis tergantung dari program komunikasi yang dibuat oleh sebuah organisasi dalam menghadapi krisis. Program komunikasi perlu mempertimbangkan beberapa hal seperti khalayak atau publik suatu organisasi, tujuan kegiatan komunikasi untuk masing-masing publik, pesan yang akan disampaikan, media komunikasi yang akan digunakan, bentuk informasi, pelaku komunikasi atau juru bicara atau sumber komunikasi krisis serta dukungan pihak luar dalam penguatan organisasi (Barton, 1993; Fearn Banks, 1996; W.Noeradi, 1997).

Pengenalan terhadap publik sasaran merupakan hal. yang penting dalam program komunikasi krisis. Dengan pemahaman yang detail terhadap publik, dapat ditentukan cara komunikasi yang paling efektif dan cara mencapai mereka. FearnBanks (1996:27) membagi publik ke dalam kategori:

a.Enabling public, yakni publik yang punya kekuasaan untuk memutuskan suatu persoalan. Termasuk di dalamnya antara lain Dewan Direktur, pemegang Saham, Komisaris perusahaan dan pemerintah. 
b. Functional public, yakni kelompok orang yang menjadikan sebuah organisasi dapat berputar . Termasuk didalamnya antara lain karyawan, konsumen, dil.

c. Normative public, yakni kelompok orang yang mempunyai kepentingan yang sama dengan organisasi. Termasuk di dalamnya adalah para anggota asosiasi atau perkumpulan perusahaan-perusahaan sejenis.

d. Diffused public, yakni kelompok orang yang secara tidak langsung berhubungan dengan organisasi dalam sebuah krisis. Yang tergolong dalam kategori ini antara lain media dan kelompokkelompok komunitas.

Pada dasarnya, masing-masing publik organisasi punya kepentingan yang berbeda-beda, sehingga suatu krisis pasti ditandai dengan adanya konflik kepentingan. Dalam situasi krisis, sebuah organisasi harus dapat melayani kepentingan berbagai publik dan hendaknya dalam menyampaikan pesan kepada publik yang berbeda-beda jangan mengandung pertentangan yang dapat memperkeruh suasana. Oleh karena itu, strategi pesan juga perlu dirancang. Isi komunikasi harus dapat memenuhi kebutuhan yang berbedabeda dari berbagai publik. Menurut Sturges, dkk. ( Ngurah Putra,1999) informasi dalam komunikasi krisis dapat berupa: a. Instructing information, yakni informasi yang pada dasarnya berisi petunjuk atau pedoman apa yang harus dilakukan oleh publik ketika ada dalam sebuah krisis. Informasi jenis ini penting karena pada saat krisis, publik menginginkan pedoman yang pasti bagi langkah mereka selanjutnya.

b. Adjusting information adalah informasi yang memungkinkan publik untuk mengatasi masalah-masalah emosional mereka, misalnya dalam kasus kecelakaan pesawat.

c. Internalizing informations adalah informasi yang akan diserap khalayak yang pada akhirnya akan membentuk penilaian publik terhadap sebuah organisasi dalam jangka panjang. Isi komunikasi biasanya menyangkut inti krisis yang sedang dihadapi langkah-larigkah apa yang akan dilakukan organisasi dalam menangani krisis.

Dalam menyampaikan pesan, perlu pula dipertimbangkan aspekaspek hukum untuk menghindari kemungkinan terjadinya tuntutan oleh publik terhadap organisasi karena menyampaikan informasi yang menyesatkan atau merugikan publik. Selain itu, saluran komunikasi atau media yang akan digunakan dalam 
menyampaikan pesan juga perlu diperhitungkan. Keefektifan komunikasi, dalam banyak hal sangat tergantung pada saluran atau media yang digunakan. Media komunikasi pribadi seperti tatap muka, pertemuan maupun media komunikasi publik seperti surat kabar, maupun televisi dapat digunakan. Yang penting dalam pemilihan pesan adalah kemampuannya dalam menyampaikan pesan dan tinggi rendahnya kadar kepercayaan publik terhadap media tersebut.

Lebih jauh menurut Coombs (Ngurah Putra, 1999:101-102), untuk merespon sebuah krisis dapat digunakan lima strategi, tergantung pada hakekat krisis yang sedang dihadapi oleh organisasi. Kelima krisis tersebut:

a. Nonexistence strategies. Strategi ini dilakukan oleh organisasi yang memang tidak.menghadapi krisis, namun ada rumor bahwa sebuah organisasi sedang menghadapi sebuah krisis/masalah serius. Dalam strategi ini, bentuk pesan bisa berupa: denial, yakni organisasi menyangkal adanya sesuatu yang tidak beres; clarification, yakni organisasi menolak dengan dibarengi argumen dan alasan mengapa tidak terjadi krisis; attack, organisasi menyerang pihak yang menyebarkan rumor dan intimidation, organisasi membuat ancaman terhadap penyebar rumor.
b.Distance strategies, yakni organisasi mengakui adanya krisis dan mencoba untuk memperlemah hubungan antara organisasi dengan krisis yang sedang terjadi. Dua hal dapat dilakukan organisasi, yakni excuse dan justifikasi. Pada excuse, organisasi berusaha untuk mengurangi tanggungjawab organisasi dengan cara penolakan maksud, bahwa organisasi tidak bermaksud melakukan hal-hal negatif dan penyangkalan kemauan, karena organisasi tidak mampu mengontrol situasi. Pada justifikasi, organisasi bisa melakúkan dengan mengklaim bahwa kerusakan yang terjadi tidak. serius, mengatakan korban wajar menangung akibat itu serta mengemukakan bahwa krisis telah salah interpretasi. Namun demikian, tingkat penolakan terhadap suatu penyebab krisis akan sangat tergantung pada jenis krisis yang dihadapi oleh suatu organisasi.

c. Ingratiation strategies yakni orgainisasi berusaha untuk mencari dukungan publik dengan menggunakan cara berikut: bolstering, yaitu organisasi perlu mengingatkan publik akan halhal positif yang telah dilakukan organisasi.; transedence, yaitu berusaha menempatkan krisis dalam konteks yang lebih besar; dan praising others, yaitu me- 
ngatakan hal-hal baik yang telah dilakukan publik.

d. Mortification strategies yakni organisasi mencoba memohon maaf dan menerima kenyataan bahwa memang benar-benar terjadi krisis. Tiga hal dapat dilakukan organisasi, yaitu remediation, repentance dan rectifyication. Pada remediation, organisasi bersedia untuk memberi sejumlah kompensasi kepada korban sebuah krisis. Pada repentance, organisasi memohon maaf atau ampun dari publik. Pada rectification, organisasi mengambil tindakan yang akan mengurangi kemungkinan terjadinya krisis.

e. Suffering strategy, yaitu organisasi menunjukan bahwa ia menderita seperti halnya pihak korban dan berusaha untuk memperoleh simpati publik.

Faktor lain yang perlu dipertimbangkan dalam suatu strategi komunikasi dalam menghadapi krisis, adalah pemanfaatan pihak ketiga sebagai pendukung posisi organisasi. Dalam berbągai kasus, dukungan dari pihak ketiga sangat efektif digunakan untuk memperkuat posisi organisasi atau memulihkan reputasi organisasi. Pihak ketiga, yakni pihak-pihak yang secara langsung tidak memiliki kaitan dengan sebuah krisis, namun merupakan pihak yang membantu posisi organisasi . Dalam hal ini, organisasi-organisasi inde- penden yang ada dalam masyarakat, pemuka masyarakat, para ulama, para pakar, adalah kekuatan yang dapat dimanfaatkan untuk menetralisir keadaan. Selain itu, tampilnya pimpinan puncak sebuah organisasi untuk terjun langsung ke lapangan melihat korban krisis menunjukkan pesan adanya perhatian dan tanggungjawab organisasi terhadap korban, baik manusia maupun lingkungan yang dihuni manusia.

Terakhir, tidak kalah pentingnya dalam suatu strategi komunikasi krisis adalah pemilihan siapa yang akan menjadi juru bicara, baik kepada berbagai publik maupun terutama kepada media massa yang akan menjadi saluran penting dalam komunikasi krisis. Apakah pimpinan puncak sebuah organisasi ataukah praktisi humas (public relations)? Dalam pemilihan juru bicara harus dipertimbangkan kredibilitas juru bicara tersebut, yaitu persepsi khalayak yang didasarkan pada keahlian dan kejujuran. Menurut FearnBanks (1996), seorang juru bicara dalam sebuah krisis harus punya sejumlah kedudukan dalam organisasi, pandai berbicara, punya kekuasaan untuk mengambil keputusan, mudah diakses saat krisis, bisa bicara dengan jelas, serta juga menarik untuk dipotret. 


\section{Penutup}

Krisis adalah suatu tuming point yang dapat membawa permasalahan ke arah yang lebih baik atau lebih buruk. Krisis yang tidak ditangani dengan baik umumnya akan berakibat buruk, kejatuhan organisasi. Sebaliknya, krisis yang dapat dipecahkan dengan baik justru akan membawa keuntungan organisasi. Oleh karenanya, organisasi yang terkena krisis harus segera bertindak sebelum krisis itu melumpuhkan sendi-sendi organisasi dan menimbulkan krisis kepercayaan yang membuat penanganan krisis menjadi suatu kemustahilan. Kumpulkan semua fakta yang ada, putuskan fakta mana yang dapat disiarkan dan kapan waktu yang tepat untuk menyiarkan, siarkan fakta secara proaktif, berikan jawaban /tanggapan secara terus terang dan terbuka dengan informasi yang aktual, tunjukkan keprihatinan/perhatian dan berkomunikasi secara terus menerus (membuka saluran komunikasi 24 jam) merupakan langkah-langkah komunikasi krisis yang perlu dilakukan setiap organisasi.

Melalui strategi komunikasi yang tepat diharapkan dapat menetralisir intervensi pihak ketiga yang mungkin dapat memperparah krisis, mengurangi ketidakpastian, karena publik memperoleh informasi yang cepat dan akurat, bahkan dukungan pihak ketiga untuk menyelesaikan krisis.

\section{Daftar Pustaka}

Barton, L. 1993. Crisis in Organizations: Managing and Communications in the Heat of Chaos. Cincinnati: South- Western Publishing.

Elvinaro Ardianto \& Soleh Soemirat. 2002. Dasar-dasar Public Relations. Bandung: Remaja Rosdakarya.

Dindin M. Machfudz. 1998. "Ketika Perusahaan Menghadapi Krisis". Artikel pada Jurnal ISKI Manajemen

Krisis, No.2/Oktober 1998.

Fearn-Banks, K. 1996. Crisis Eommunications: A casebook Approach . Mahwah NJ: Lawrence Eribaum.

I Gusti Ngurah Putra. Manajemen Hubungan Masyarakat. Yogyakarta: Penerbit Universitas Atma Jaya.

Mazur, Laura \& John White.1998. Manajemen Krisis (alih bahasa Miftah F.Rakhmat). artikel pada Jurnal ISK Manajemen Krisis, No. 2/Oktober 1998.

Parrow, Richard W. 1998. Cara Berkomunikasi dalam Situasi Krisis, artikel pada Jurnal ISKI Manajemen Krisis, No. 2/Oktober 1998.

Rhenald Kasali.1999. Manajemen Public Relations. Konsep dan Aplikasinya di Indonesia. Jakarta: Grafiti 
Rosady Ruslan. 1999. Praktik dan Solusi Public Relations dalam Situasi Krisis dan Pemulihan Citra. Jakarta: Ghalia Indonesia.

Wicaksono Noeradi. 1997. Upaya Memudahkan Komunikasi Saat Terjadi Krisis, Makalah Seminar Crisis Communication Planning, Yogyakarta, 6 Desember1997.

\section{Biodata Penulis}

Lena Satlita, adalah staf pengajar Program Studi Pendidikan Administrasi Perkantoran Fakultas limu Sosial Universitas Negeri Yogyakata (FIS UNY). Menamatkan studi S1 di Fisipol UGM, Jurusan Administrasi Negara dan S2 di Pasca Sarjana UGM, Jurusan IImu Politik. 